\title{
The Digital Divide: Examining the Use and Access to E-Health Based Technologies by Millennials and Older Adults
}

\author{
Delana Theiventhiran, BHSc, MHSc ${ }^{1}$, Dr. Wally J. Bartfay, RN, $\mathrm{PhD}^{2^{*}}$, Dr. Caroline Barakat \\ Haddad $^{3}$, Dr. Terry Wu ${ }^{4}$
}

${ }^{\mathrm{T}}$ Faculty of Health Sciences, Ontario Tech University, 2000 Simcoe St N, Oshawa ON, L1H 7K4, Canada

${ }^{2}$ Faculty of Health Sciences, Ontario Tech University, 2000 Simcoe St N, Oshawa ON, L1H 7K4, Canada

${ }^{3}$ Faculty of Health Sciences, Ontario Tech University, 2000 Simcoe St N. Oshawa ON, L1H 7K4, Canada

${ }^{4}$ Faculty of Business and IT, Ontario Tech University, 2000 Simcoe St N., Oshawa ON, L1H 7K4, Canada

\section{*Corresponding Author}

Dr. Wally J. Bartfay

\section{Article History}

Received: 22.01.2020

Accepted: 29.01 .2020

Published: 29.02 .2020

\begin{abstract}
Objectives: The digital divide is a complex phenomenon in which a metaphorical gap is present in between two groups of individuals who utilize ICT's (information communication technologies). This gap provides cause for concern, especially with a society that is so technologically advanced in todays' day. Currently, little is known about how older adults and millennials access and use e-health based technologies. Hence, a systematic review was undertaken to address this noted gap in the literature. Methods: A systematic review of the literature was undertaken employing the following three databases (i) PubMed, (ii) ERIC, and (iii) CINAHL were examined using the search term "digital divide and generations" to identify potential articles were present. A data abstraction tool was created to obtain the following information: (i) author, (ii) year of publication, (iii) sample size, (iv) country of origin, (v) design/methods, (vi) major findings/outcomes obtained. Inclusion criteria included publication dates between the years of Jan 2009 to Aug 2018 , written in the English language, targeting the target population of older adults aged $65+$ and millennials, as well as being peer reviewed quantitative articles. Results/Conclusion: There is a dearth of literature in this topic, as well as a decline of research produced from Canada. The consequences and benefits of technology being integrated into daily living are just being investigated. Additionally, a change in the way that healthcare is currently used, received and distributed would also help attribute to the change to ensure that no generation is left behind in a technologically advanced society.
\end{abstract}

Keywords: Digital divide, information communication technologies, ICT, older adults, millennials, technology, Internet, E-health.

\section{INTRODUCTION}

Currently, there is a death of literature examining the use of technology to access health related information. The digital divide is a phenomenon that describes the divide between groups when utilising information communication technologies (ICTs) to help better their experience in society. Technology usage has widely been associated with those in the millennial generation, who are defined as individuals born between the years of 1981 to 2000 [1]. Milestones of their generation include the rise of technology such as smartphones and tablets, social media, as well as entering the work force during the economic recession [1]. Most millennials in today's day would be between the ages of 18 and 37 . Older adults were born between 1946 and 1965, and would be between the ages of 54 and 72 . With the rise of technology usage in society, those in the older adult generation may not be as familiar with technology and are thus put at a disadvantage compared to other generations such as millennials when examining and using e-health based platforms and technology.

Copyright @ 2020: This is an open-access article distributed under the terms of the Creative Commons Attribution license which permits unrestricted use, distribution, and reproduction in any medium for non commercial use (NonCommercial, or CC-BY-NC) provided the original author and source are credited. 


\section{OBJECTIVES}

This systematic review aims to identify the gaps that led to the digital divide between older adults and millennials, and identify ways to rectify this gap to be inclusive of all generations.

\section{Significance and Rationale}

Technology is used worldwide, and has become a major driving factor for many occupations, schooling \& training, banking, shopping and even daily living as a form of socialization and entertainment. These daily activities have been converted onto the online platform, so individuals can enjoy the convenience of doing daily activities from the comfort of their own homes, or on the go. Internet users from the ages of 34 and younger has increased substantially from 72.6 in 2005 to 82.9 in 2009 , moreover those aged 65 and older have also increased as well from $62.8 \%$ in 2005 to $65.9 \%$ in 2009 [2]. However, in a technologically advanced society, it is important to note that not everyone is familiar or comfortable with using these technologies. Although technology usage has increased exponentially over the past few decades, the generation of those aged 65 and older are still not fully online and integrated into the online platform.

This unfamiliarity of technology and a lack of usage is what present itself as the so-called "digital divide". The term "digital divide" was first coined to describe the noted gaps between different generations when they are utilising technology and information communication technologies. In comparison, older adults are not online as much and prefer traditional methods such as pamphlets and face-to-face contact with their health care providers to obtain their health information. Although those methods are valid ways to receive information, those who are $65+$ are at a disadvantage when the online world provides them with significantly more up-to-date resources, such as Health Canada, Public Health Canada, government and not for profit NGO websites. These websites are able to provide a plethora of information for individuals who may be experiencing ailments that could be treated at home or over the counter. By accessing these online resources, these individuals are able to save time and health care expenses by avoiding a trip to their health provider or emergency room.

Despite the growth and the use of Internet based health related websites on various topics such as chronic and infectious disease, medications, nutrition and diets, there is currently a death of information related to who is actually accessing and how they are using these websites. Accordingly, a systematic review of the peer-reviewed literature was undertaken to address this noted gap and examine how older individuals compare to millennials in regards to access and usage of Internet based e-health related technology.

\section{METHODS}

A systematic review of the literature was undertaken to examine the peer-reviewed literature related to the use and excess of Internet-based technologies and sites by those aged $65+$ and millennials. Prior to the review of the literature, a preliminary search were completed to ensure that there were no similar systemic reviews studies conducted. For the purpose of this systemic review, we examined the following three online computer databases: (i) PubMed; (ii) CINAHL, and (iii) ERIC. Preliminary searches consisted of the key terms "digital divide AND generations", and a combination of different search terms to outline "digital divide and older adults" (ie. Older adults, elderly, 65+) as well as for millennials (ie. Young adults, university students, college students). Inclusion criteria for the systematic review included the following: (i) Published quantitative peer-reviewed articles published between the years January 2000 and May 2018; (ii) English only; (iii) Studies had to focus on the target population for the review compromised of those aged $65+$ and millennials only (iv) Studies had to be qualitative in nature. Exclusion criteria for the systematic review included: (i) letters to the editor (ii) theory-focused articles and (iii) non-English articles. A data abstraction template was employed to assess the suitability of the articles, and compromised the following information: (i) type of article (research-based, quantitative, system review); (ii) ranking of article in the order listed in Flow Chart II (iii) authors; (iv) year of publication; (v) country of origin); (vi) main outcomes and/or conclusions. Once potential abstracts were located, articles were examined for their suitability. The reference lists for all located suitable articles were also examined for potential secondary data sources. Following the initial preliminary search, multiple other searches were employed using terms such as "65+" such as "elderly", and "senior", to ensure all potential and relevant articles were identified.

\section{RESULTS/FINDINGS PubMed}

The initial search on PubMed provided 505 potential articles. Following that search, inclusion criteria was manually applied, which brought down the list to 27 articles. After examining for suitability, 23 articles were selected and the data abstraction tool was then employed to extract data from the study. 
ERIC

The initial search performed on ERIC provided 53 potential articles. Following the application of the inclusion criteria, that list was brought down to 11 potential articles. After examining for suitability, no articles were found to be suitable for the purpose of this study.

\section{CINAHL}

The initial search performed on CINAHL provided 14 potential articles. Following the application of the inclusion criteria, the list presented 12 hits. After examining for suitability, the list was brought down to eight hits, and had the data abstraction tool applied to extract relevant data from the study.

Table-1: Summary of PubMed, ERIC, and CINAHL Articles

\begin{tabular}{|c|c|c|c|}
\hline $\begin{array}{l}\text { Authors and Country } \\
\text { of Origin }\end{array}$ & Design/Methods & Major Outcomes & Ranking \\
\hline $\begin{array}{l}\text { Bhuyan, Lu, Chandak, et } \\
\text { al. [3]- } \\
\text { USA }\end{array}$ & $\begin{array}{l}\text { - } \quad \text { Looked at mobile health } \\
\text { applications for health } \\
\text { behaviours. } \\
\text { - } 36 \% \text { of individuals had health } \\
\text { apps } \\
\text { - } 60 \% \text { reported usefulness of } \\
\text { health apps in health behaviour } \\
\text { goals. } \\
\text { - } 35 \% \text { stated there was } \\
\text { helpfulness in medical care } \\
\text { section making } \\
\text { 38\% reported usefulness in } \\
\text { asking physicians new questions. }\end{array}$ & $\begin{array}{l}\text { Mobile health apps can reduce the } \\
\text { burden on primary care, reduce } \\
\text { costs and improve quality on health } \\
\text { care. } \\
\text { There is also a privacy concern on } \\
\text { who has access to information in } \\
\text { the mobile health apps. }\end{array}$ & III \\
\hline $\begin{array}{l}\text { Cresci, Yarandi, Morrell. } \\
\text { [4]- } \\
\text { USA }\end{array}$ & $\begin{array}{l}\text { Examined the health, } \\
\text { demographic and social } \\
\text { activities of urban older adults. } \\
\text { Secondary analysis via } 2001 \\
\text { Detroit citywide assessment of } \\
\text { older adults. }\end{array}$ & $\begin{array}{l}\text { Computer users were younger, had } \\
\text { a high level of employment and } \\
\text { education, and were healthier and } \\
\text { more active. } \\
\text { Internet was used to connect with } \\
\text { friends and family and playing } \\
\text { games, and writing. }\end{array}$ & III \\
\hline $\begin{array}{l}\text { Delello, \& McWhorter. } \\
\text { [5]- } \\
\text { USA }\end{array}$ & $\begin{array}{l}\text { Those } 65+\text { are experiencing } \\
\text { social isolation, loneliness, } \\
\text { depression and decline in health. } \\
\text { The study looks to find if ICTs } \\
\text { (ipads) improved the lives of } \\
\text { older adults }\end{array}$ & $\begin{array}{l}\text { Use of technology brought } \\
\text { increased knowledge, closer gamily } \\
\text { ties, and a greater connection to } \\
\text { society. }\end{array}$ & III \\
\hline $\begin{array}{l}\text { Duplaga [6]- } \\
\text { Poland }\end{array}$ & $\begin{array}{l}\text { Examined looking at Internet } \\
\text { usage with those who have } \\
\text { disabilities on a nationwide } \\
\text { study in } 2013 \text { in Poland }\end{array}$ & $\begin{array}{ll} & 33.05 \% \text { were Internet users } \\
\text { - } & 3556 \text { respondents with disability } \\
& 51.02 \% \text { were females } \\
\text { - } & 25.19 \% \text { were } 65+\end{array}$ & III \\
\hline $\begin{array}{l}\text { Gracia, \& Herrero [2] - } \\
\text { Spain }\end{array}$ & $\begin{array}{l}\text { - Aims to look at the association } \\
\text { between Internet use and self- } \\
\text { rated health in older people and } \\
\text { see if there is an interaction } \\
\text { when examining socioeconomic } \\
\text { status. } \\
709 \text { individuals were examined } \\
\text { in Spain, and were compared } \\
\text { using two age groups (55-64 and } \\
65-74 \text { years of age). }\end{array}$ & $\begin{array}{l}\text { Relationship between Internet } \\
\text { usage and poor self rated health, } \\
\text { which supported the notion that } \\
\text { Internet users have better self rated } \\
\text { health then those who are non } \\
\text { users. } \\
\text { When applied using social class, } \\
\text { the relationship was eliminated, } \\
\text { which suggest that the Internet is } \\
\text { not a significant determinant of } \\
\text { health in older people. }\end{array}$ & III \\
\hline $\begin{array}{l}\text { Hong, Cho. [7]- } \\
\text { USA }\end{array}$ & $\begin{array}{l}\text { - } 2003 \text { to } 2011 \text { using the HINTS } \\
\text { survey. } \\
\text { Examined by } 4 \text { online } \\
\text { behaviours: seeking health info, } \\
\text { buying medicine, connecting } \\
\text { with people who have similar } \\
\text { health problems, and } \\
\text { communicating with doctors. }\end{array}$ & $\begin{array}{l}\text { Digital health divide between } \\
\text { different demographic groups is } \\
\text { narrow but those who are older, do } \\
\text { not have a HS education, and low } \\
\text { income lagged }\end{array}$ & III \\
\hline $\begin{array}{l}\text { Hong, et al. [8]- } \\
\text { China }\end{array}$ & $\begin{array}{l}\text { Examine the current rates of } \\
\text { access to mobile tools among } \\
\text { Chinese individuals aged } 45+\text {. }\end{array}$ & $\begin{array}{l}\text { - } 18215 \text { participants, } 6.51 \% \text { used } \\
\text { Internet in the past month } \\
\text { - } \quad 83 \% \text { owned a mobile phone } \\
\end{array}$ & $\mathrm{V}$ \\
\hline
\end{tabular}




\begin{tabular}{|c|c|c|c|}
\hline & $\begin{array}{l}\text { - Used neighbourhood amenities } \\
\text { and community level resources }\end{array}$ & $\begin{array}{l}\text { Divide is present in china in an } \\
\text { older population. Internet access is } \\
\text { limited to people with higher SES. }\end{array}$ & \\
\hline $\begin{array}{l}\text { Hurme, Westerback, \& } \\
\text { Quadrello [9]- Finland }\end{array}$ & $\begin{array}{l}\text { Sample of Finnish grandchildren } \\
\text { and grandparents; examining } \\
\text { distance, age, gender, and } \\
\text { education for grandparents. }\end{array}$ & $\begin{array}{l}\text { The further the grandparent lives, } \\
\text { the further the face-to-face contact } \\
\text { is, but more letters and cards. } \\
\text { Grandchildren tend to use text } \\
\text { messaging instead. }\end{array}$ & I \\
\hline $\begin{array}{l}\text { Kania-Lundholm, Torres } \\
{[10]-} \\
\text { Sweden }\end{array}$ & $\begin{array}{l}\text { Research on older active ICT } \\
\text { users looks at why those who are } \\
\text { older age consider themselves as } \\
\text { unable to use technology }\end{array}$ & $\begin{array}{l}\text { Interviews with } 30 \text { older adults } \\
\text { (Aged 66-89). } \\
\text { Positioning theory is used to shed } \\
\text { light on how the older people } \\
\text { interview positioned as active older } \\
\text { issues. }\end{array}$ & III \\
\hline $\begin{array}{l}\text { Levy, Janke, Langa. } \\
\text { [11]- } \\
\text { USA }\end{array}$ & $\begin{array}{ll}\text { - } & \text { Health literacy and use of } \\
\text { Internet for obtaining health } \\
\text { info. } \\
\text { - } \\
\text { - } \\
\text { Among Americans } 65+\text { Sample size was } 824 \text { individuals } \\
\text { and } 1584 \text { Internet users. }\end{array}$ & 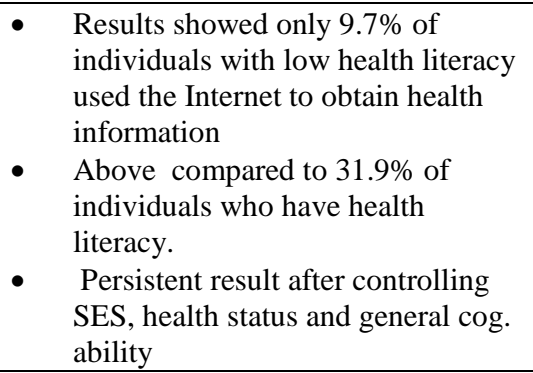 & III \\
\hline $\begin{array}{l}\text { Levy, Janke, \& Langa } \\
{[11]-} \\
\text { USA }\end{array}$ & $\begin{array}{l}\text { Cross sectional survey using } 225 \\
\text { adults to examine if HIT is able } \\
\text { to improve quality of care and } \\
\text { health outcomes. }\end{array}$ & $\begin{array}{l}\text { 76\% of respondents had Internet } \\
\text { access, users and nonusers of } \\
\text { online health info differed. } \\
\text { Those who used laptops, } \\
\text { computers, and smartphones were } \\
\text { more likely to be efficient in HIT. }\end{array}$ & $\mathrm{V}$ \\
\hline $\begin{array}{l}\text { Luger, Hogan, } \\
\text { Richardson, Cioffari- } \\
\text { Baillif, Harvey, \& } \\
\text { Houston [12]- } \\
\text { USA }\end{array}$ & $\begin{array}{l}\text { - } \text { Older adults have less access to } \\
\text { Internet } \\
\text { Data collected via mail survey } \\
\text { with a sample of } 266 \text { veterans } \\
\text { aged } 65+\text {. } \\
\text { 50\% reported having no Internet } \\
\text { access but they reported feeling } \\
\text { comfortable with help to access } \\
\text { Internet. }\end{array}$ & $\begin{array}{l}\text { Older individuals are willing to } \\
\text { access the Internet if they have } \\
\text { technology support. }\end{array}$ & III \\
\hline $\begin{array}{l}\text { Mackert, Mabry-Flynn, } \\
\text { Champlin, Donovan, \& } \\
\text { Pounders [13]- } \\
\text { USA }\end{array}$ & $\begin{array}{l}\text { 4974 American adults were } \\
\text { looked at to examine if health } \\
\text { literacy affected HIT use. }\end{array}$ & $\begin{array}{l}\text { Patients with low health literacy did } \\
\text { not use HIT tools as much but they } \\
\text { thought HIT use was private. } \\
\text { It is important to examine the way } \\
\text { that HIT provides privacy and that } \\
\text { individuals are able to use full } \\
\text { benefits. }\end{array}$ & IV \\
\hline $\begin{array}{l}\text { Nguyen, Mosadeghi, \& } \\
\text { Almario [14] } \\
\text { United States of America }\end{array}$ & $\begin{array}{l}\text { 81.5\% of individuals reported } \\
\text { using the Internet previously. } \\
64.5 \% \text { stated that they used the } \\
\text { Internet within the past year. }\end{array}$ & $\begin{array}{l}\text { Individuals who lived in lower } \\
\text { income households and rural areas } \\
\text { were less likely to have access to } \\
\text { use Internet for health information. }\end{array}$ & III \\
\hline $\begin{array}{l}\text { Seifert, \& Schelling [15]- } \\
\text { Switzerland }\end{array}$ & $\begin{array}{l}\text { - } \begin{array}{l}\text { Examined those aged } 65+\text { living } \\
\text { in Switzerland via telephone } \\
\text { survey. }\end{array} \\
\end{array}$ & $\begin{array}{l}\text { Those online found better positive } \\
\text { aspects of the Internet compared to } \\
\text { those who didn't. }\end{array}$ & III \\
\hline $\begin{array}{l}\text { Van Deursen, \& Van } \\
\text { Dijk. [16] -Netherlands }\end{array}$ & $\begin{array}{l}\text { E-Health literacy is one of the } \\
\text { bigger aspects that have been } \\
\text { presented following the increase } \\
\text { of technology in health care. } \\
88 \text { subjects participated in the } \\
\text { study. } \\
\text { Each subject had to work on } \\
\text { assignments through the Internet } \\
\text { and focused on areas such as } \\
\text { operational, formal, } \\
\text { informational and strategic. }\end{array}$ & $\begin{array}{l}\text { - } \quad \text { Unable to find out who is proficient } \\
\text { in technology vs who is not. } \\
\text { - } \quad \text { Subjects were able to complete } \\
73 \% \text { of the Internet tasks } \\
\text { - } 73 \% \text { of the formal tasks } \\
\text { - } 50 \% \text { of Internet tasks were } \\
\text { completed } \\
\text { - } 13 \% \text { for informational skills } \\
\text { - } \\
\text { Age and education were crucial } \\
\text { contributors in this area. }\end{array}$ & III \\
\hline
\end{tabular}




\section{DireCtions FOR FUTURE RESEARCH \\ Gaps in the Literature}

There is currently a death of literature examining the digital divide and the interaction between the millennial and older adult generation, in comparison to use for health related information. This is a cause for issue as technology is becoming increasingly integrated in society, (ie.smartphones, laptops, and tablets). These information communication technologies have also become critical assets to receive up-to-date health information. As a result, 86\% of Canadians have become technology users, Statistics Canada, 2016. Statistics Canada 2016 also shows that the majority of nontechnology users are those who are older adults and are not as accustomed to having technology integrated as a part of their lifestyles.

\section{Age}

Age was found to be one of the largest supporting factors in contributing to the digital divide. Many of the articles $(\mathrm{N}=11)$ indicated that age is one of the larger factors contributing to the digital divide. This can be attributed to the reasoning that millennials grew up with technology [9], and tend to use technology such as social media as a main form of communication [16]. Additionally, technology is largely used in the school and work setting to help support regular daily processes, applications and requirements. In regards to those $65+$, they were found to be not as familiar with technology $(\mathrm{N}=5)$, and only utilize technology when actually required. Those aged $65+$ were also found to need help to use technology [12].

A study by Loges and Jung [17]) also examined the digital divide and the relationship it has with age. They hypothesized that age has a negative association with Internet access. The study found that age leads to a change in the way that the participants respond on surveys. They also use less Internet-based applications, and use it less compared to their younger counterparts. Friemal [18] found that those individuals aged 65 years and older were partially excluded from Internet usage. Friemal [18] identified that social context has an increased influence on whether someone aged 65+ would be using the Internet or not. The studies by Korrupp and Szydlik [10] and Loges and Jung [17] further prove that age and the instances of usage often correlate with the level of familiarity an individual has with using the Internet.

\section{Health Information Technology Usage}

Nearly all Canadians under the age of 45 use the Internet every day [19]. This statistic states that usage decreases with increasing age, with those aged 65 and over reporting that the Internet used on occasion, or as required.

\section{Privacy Concerns}

Many of the examined articles $(\mathrm{N}=5)$ identify that privacy concerns were one of the main deterrents of technology usage for elderly individuals aged 65 and over. The older adult generation feels that privacy is one of the biggest concerns, especially in regards to the collection and usage of data that is collected by Internet applications and website developers. Other concerns involve $\mathrm{t}$ third parties involved and how they collect and store personal information. Younger generations were also giving away their personal information and data. Terms and conditions that were outlined in apps were often difficult to read, especially when they are filled with pages of technical terms. An academic paper written by Obar aand Oeldorf-Hirsch [20] outlines that online users tend to agree to terms of services and privacy policies $93 \%$ and $97 \%$ of the time, respectively. This is a cause for concern as the privacy policy and the terms of service should have taken between 29 and 32 minutes to read, which did not happen with the majority of participants $(\mathrm{N}=543)$. Many older adults indicate that terms and conditions are often long and extensive, which deters them away from trying new E-health technology (ie. app to measure heart rate and heart beat).

\section{Digital Literacy}

Digital literacy is the notion of how well an individual is able to use information communication technologies for processes such as research and knowledge retention, mechanical, as well as social application. According to Statistics Canada [19], there are many barriers to digital literacy, such as the attitude involving technology, age, socioeconomic status (SES), languages, and the general availability and access to these resources.

\section{Access to the Internet}

Access to technology and the internet also plays a large part in the way that individuals are able to receive and use information. The Canadian Radio-Television and Telecommunications Commission has stated that broadband internet is an essential service that should be delivered to all Canadians equally and adequately [6]. According to the Canadian Broadcasting Corporation, Canada has many Internet "dead zones", which are areas where infrastructure for Internet connection has not been placed. These "dead zones" are often seen as an individual moves further north and away from urban centres [6]. As a result, many smaller towns have been introducing their own broadband infrastructure to help combat that situation and provide equal access to the internet for all. With Canada's population largely being centered in urban centres, it still creates a concern for those who are in rural locations. 


\section{Implications for Public Health}

The digital divide is still a large problem in society, and now that we have examined various factors (such as age, education, IT literacy and sociodemographic factors) leading to the gap being present, we can now examine the impact of the digital divide on health information received, used, distributed and collected by different generations. Practically speaking, identifying how newer healthcare technology can be integrated into society and identifying why there is a gap with digital technology will help reduce the impact on generations and individuals who are not as familiar with technology and Internet usage as their younger counterparts. The comprehension and understanding of this issue is important in today's day to reduce the digital divide would include identifying where there is a lack of access to the Internet and can be improved. The digital divide was attributed as one of the main causes, with the digital divide being defined as the notional gap that divides one generation from another due to a lack of comprehension involving the general usage of technology. This systematic review specifically targeted those who are aged $65+$ and between 18-24 to examine the two extremes of technology usage. By investigating this and aiming to identify if any prior research had taken place, it was found that there was a death of literature in this area especially because it is a newer area of research. The consequences and benefits of technology being integrated into daily living is just being investigated. Another important aspect to consider is that there is also a death of literature on research that is being produced by Canada. The majority of the literature in this topic is produced is American descent. Additionally, a change in the way that healthcare is currently used, received and distributed would also help attribute to the change to ensure that no generation is left behind in a technologically advanced society.

The largest concern of all is how to prepare older adults for new and emerging e-health technologies. Older adults are just at $65.9 \%$ of the population who use technology, whereas the millennials are almost fully integrated at $98 \%$ [19]. With the increasing costs of healthcare, learning how to use technology can help support many older adults with their health care resources and reduce costs. With the proper support, older adults can learn how to use technology to help better their quality of life and reduce health care spending costs at the same time.

\section{REFERENCES}

1. Pew Research Center. (2018, May 02). Millennials stand out for their technology use. Retrieved from http://www.pewresearch.org/fact-tank/2018/05/02/millennials-stand-out-for-their-technology-use-but-oldergenerations-also-embrace-digital-life/

2. Gracia, E., Herrero, J. (2009). Internet Use and Self-Rated Health among Older People: A National Survey. Journal of Medical Internet Research,11(4).

3. Bhuyan, S. S., Lu, N., Chandak, A., Kim, H., Wyant, D., Bhatt, J., ... \& Chang, C. F. (2016). Use of mobile health applications for health-seeking behavior among US adults. Journal of medical systems, 40(6), 153.

4. Cresci, M. K., Yarandi, H. N., \& Morrell, R. W. (2010). The digital divide and urban older adults. CIN: Computers, Informatics, Nursing, 28(2), 88-94.

5. Delello, J. A., \& McWhorter, R. R. (2017). Reducing the digital divide: Connecting older adults to iPad technology. Journal of Applied Gerontology, 36(1), 3-28.

6. Duplaga, M. (2017). Digital divide among people with disabilities: Analysis of data from a nationwide study for determinants of Internet use and activities performed online. PloS one, 12(6).

7. Hong, Y. A., Zhou, Z., Fang, Y., \& Shi, L. (2017). The digital divide and health disparities in China: evidence from a national survey and policy implications. Journal of medical Internet research, 19(9), e317.

8. Hong, Y. A., \& Cho, J. (2017). Has the digital health divide widened? Trends of health-related internet use among older adults from 2003 to 2011. Journals of Gerontology Series B: Psychological Sciences and Social Sciences, 72(5), 856-863.

9. Hurme, H., Westerback, S., \& Quadrello, T. (2010). Traditional and new forms of contact between grandparents and grandchildren. Journal of Intergenerational Relationships, 8(3), 264-280.

10. Kania-Lundholm, M., \& Torres, S. (2015). The divide within: Older active ICT users position themselves against different 'Others'. Journal of aging studies, 35, 26-36.

11. Levy, H., Janke, A. T., \& Langa, K. M. (2015). Health literacy and the digital divide among older Americans. Journal of general internal medicine, 30(3), 284-289.

12. Luger, T. M., Hogan, T. P., Richardson, L. M., Cioffari-Bailiff, L., Harvey, K., \& Houston, T. K. (2016). Older veteran digital disparities: examining the potential for solutions within social networks. Journal of medical Internet research, 18(11), e296.

13. Mackert, M., Mabry-Flynn, A., Champlin, S., Donovan, E. E., \& Pounders, K. (2016). Health literacy and health information technology adoption: the potential for a new digital divide. Journal of medical Internet research, 18(10), e264.

14. Nguyen, A., Mosadeghi, S., \& Almario, C. V. (2017). Persistent digital divide in access to and use of the Internet as a resource for health information: Results from a California population-based study. International journal of medical informatics, 103, 49-54.

15. Seifert, A., \& Schelling, H. R. (2018). Seniors online: Attitudes toward the internet and coping with everyday 
life. Journal of Applied Gerontology, 37(1), 99-109.

16. Van Deursen, A. J., \& van Dijk, J. A. (2011). Internet skills performance tests: are people ready for eHealth?. Journal of medical Internet research, 13(2), e35.

17. Loges, W. E., \& Jung, J. Y. (2001). Exploring the digital divide: Internet connectedness and age. Communication research, 28(4), 536-562.

18. Jang, H., Friemel, G., Ollivier, J., Dukhnenko, A. V., Shitsevalova, N. Y., Filipov, V. B., ... \& Inosov, D. S. (2014). Intense low-energy ferromagnetic fluctuations in the antiferromagnetic heavy-fermion metal CeB 6. Nature materials, 13(7), 682-687.

19. Allen, M. (2016). Police-reported crime statistics in Canada, 2015. Statistics Canada.

20. Obar, J. A., \& Oeldorf-Hirsch, A. (2016). The Biggest Lie on the Internet: Ignoring the Privacy Policies and Terms of Service Policies of Social Networking Services. SSRN Scholarly Paper ID 2757465. Social Science Research Network, Rochester, NY. https://papers. ssrn. com/abstract, 2757465.

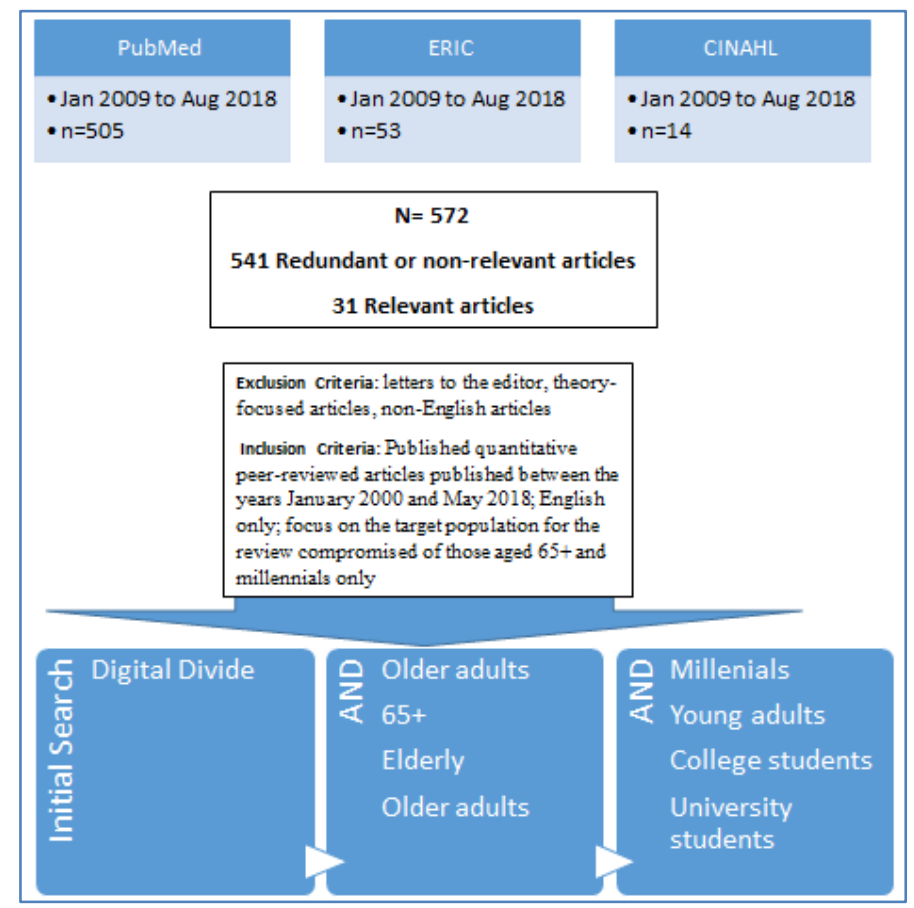

Flow Chart I: Systematic Review Searches

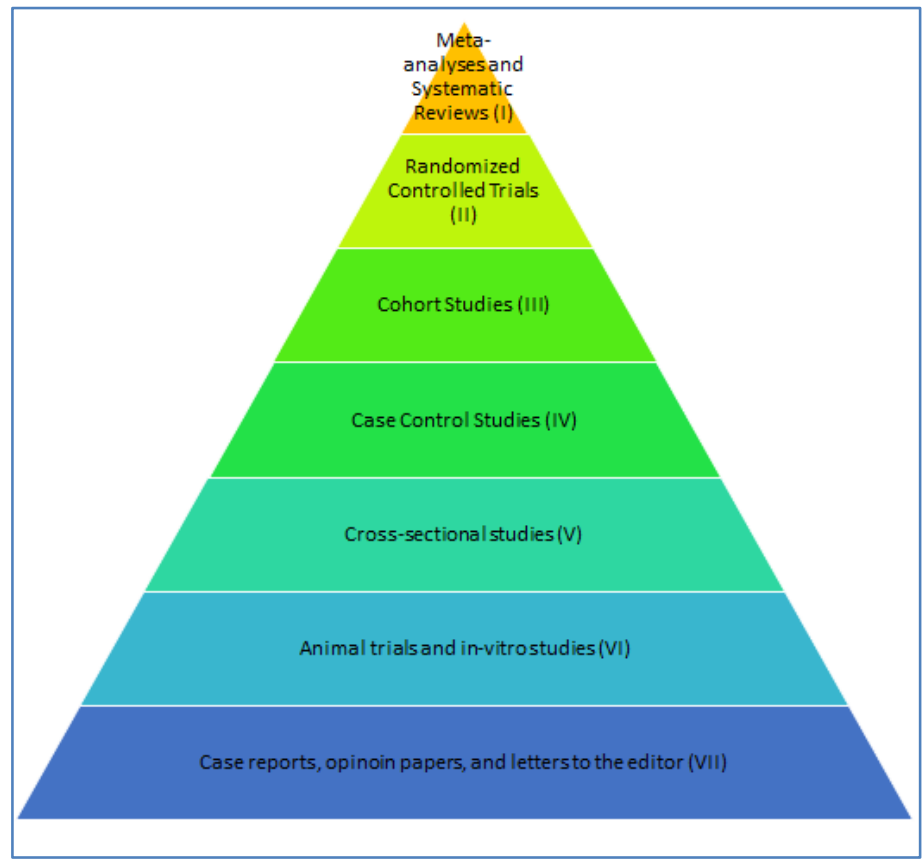

Flow Chart-II: Ranking System for Academic Sources 